\title{
EFEKTIFITAS PENGENDALIAN GULMA DAN PEMBERIAN PUPUK KANDANG AYAM TERHADAP PERTUMBUHAN DAN HASIL BAWANG MERAH (Allium ascalonicum, L) PADA TANAH MASAM
}

\author{
Gusni Yelni \\ Fakultas Pertanian, Universitas Muara Bungo \\ Email: gusni_yelni@yahoo.co.id
}

Naskah Diterima Februari 2019, disetujui Maret 2019

\begin{abstract}
This study aims to determine the effectiveness of Weed Weeding with different weeding times and to determine the effectiveness of the use of chicken manure on the growth and production of shallots (Allium ascolanicum, L). This experiment used factorial Randomized Block Design (RBD). The first factor 5 treatment consists of; PG0 (without weeding weeds), G1 (weed 1 time age, 28 days), G2 (weed 2 times age 21, and 42 hst), G3 (weed 3 times age, 14, 28, and 42 hst), G3 (3 times age, 14, 28, and 42 days), and G4 (4 times age 7, 14, 21 and 28 days). The second factor 3 treatment consists of; P1 (10 ton ha $\left.{ }^{-1}\right)$, P2 (20 ton ha $\left.{ }^{-1}\right)$, and P3 (40 ton $\mathrm{ha}^{-1}$ ) and 3 groups. The results showed that the treatment of weed weeding and administration of chicken manure organic fertilizer had a significant effect on plant height, number of children, number of plants, fresh weight of plants, and dry weight per plot. Weed control that was effective in increasing the growth of the number of tillers and onion production was, when weed control was twice, at 28 and 42 HST. The dosage of 40 ton h$^{-1}$ organic fertilizer for chicken coop is quite effective to help the growth of plant height, number of leaves and increase the weight of red onion bulbs, and improve acid soil $\mathrm{pH}$ conditions
\end{abstract}

Keywords: Onion Varieties Thailand, Weeding Time, Weed, Growth, Yield, Chicken Manure, Growth and Result of Keywords:

\begin{abstract}
ABSTRAK
Penelitian ini bertujuan untuk mengetahui tingkat efetifitas Penyiangan Gulma dengan waktu penyiangan berbeda dan untuk mengetahui efektifitas pengunaan pupuk kandang ayam terhadap pertumbuhan dan produksi tanaman bawang merah (Allium ascolanicum, L). Percobaan ini menggunakan Rancangan Acak Kelompok (RAK) faktorial. Faktor pertama 5 perlakuan terdiri atas; PG0 (tanpa penyiangan gulma), G1 (disiang 1 kali, yaitu pada umur ; 28 hst), G2 (disiang 2 kali, yaitu pada umur ; 21, dan 42 hst), G3 (disiang 3 kali, yaitu pada umur ; 14, 28, dan 42 hst), G3 (disiang 3 kali, yaitu pada umur ; 14, 28, dan 42 hst), dan G4 (disiang 4 kali, yaitu pada umur ; 7, 14, 21, dan 28 hst). .Faktor kedua 3 perlakuan terdiri atas; P1 (10 ton ha $\left.{ }^{-1}\right)$, P2 $\left(20\right.$ ton ha $\left.{ }^{-1}\right)$, dan P3 $\left(40\right.$ ton ha $\left.^{-1}\right)$ dan 3 kelompok. Hasil penelitian menunjukan bahwa perlakuan waktu penyiangan gulma dan pemberian dosis pupuk organik kandang ayam berpengaruh nyata terhadap tinggi tanaman, jumlah anakkan, jumlah duan, berat segar perumpun, dan berat kering per petak. Pengendalian gulma yang efektif dalam meningkatkan pertumbuhan jumlah anakan dan produksi tanaman bawang merah adalah, waktu penngendalian gulma sebanayk 2 kali yaitu pada umur 28 dan $42 \mathrm{HST}$. Dosis 40 ton $\mathrm{h}^{-}$ ${ }^{1}$ pupuk organik kandang ayam cukup efektif membantu pertumbuhan tinggi tanaman, jumlah daun dan meningkatkan bobot umbi tanaman bawang merah, serta memperbaiki kondisi $\mathrm{pH}$ tanah masam
\end{abstract}


Kata Kunci : Bawang Merah Varietas Thailand, Waktu penyiangan, gulma, pertumbuhan, hasil, Pupuk Kandang Ayam, Pertumbuhan dan Hasil Kata Kunci:

\section{PENDAHULUAN}

Bawang merah

(Allium

ascolanicum, L) sebagai komoditi penting yang disukai masyarakat Indonesia yang dimanfaatkan sebagai bahan masakan dan obat-obatan. Hidayat, (2010), menyatakan bahwa setiap 100 gram umbi bawang merah mengandung $88 \mathrm{~g}$ air, 9,2 $\mathrm{g}$ karbohidrat, 1,5 g protein, 0,3 g lemak, dan 0,03 kalori.

Petani yang ada di Indonesia membudidayakan dan menjadikan tanaman bawang merah sebagai salah satu usaha tani komersial. Data produksi bawang merah di Indonesia tahun 2015 adalah 1.229.184 ton dengan produktivitas 10,06 ton $\mathrm{ha}^{-1}$, dan mengalami peningkatan pada tahun 2016 yaitu mencapai 1.446.860 ton dengan produktivitas 9,67 ton $\mathrm{ha}^{-1}$ (Direktorat Jenderal Hortikultura dan BPS 2017). Produksi bawang merah di Provinsi Jambi pada tahun 2015 sebesar 3.937 ton dengan luas panen 527 ha, dan mengalami peningkatan pada tahun 2016 yaitu mencapai 4.940 ton dengan luas panen 527 ha (BPS 2017). Peningkatan hasil produksi bawang merah di berbagai Daerah yang ada di Indonesia setiap tahun belum bisa memenuhi permintaan masyarakat, dan perlu adanya perbaikan teknik budidaya serta perluasan areal tanam bawang merah sehingga kebutuhan masyarakat akan bawang merah dapat terpenuhi.

$$
\text { Teknik penentuan waktu }
$$

pengendalian gulma dan pemberian pupuk organik merupakan salah satu cara yang bisa dilakukan, terutama pada lahan-lahan pertanian yang mengalamai permasalahan kekeringan, tanah-tanah masam serta kurang tersedianya unsur hara makro dan mikro dalam tanah.

$$
\begin{aligned}
& \text { Gulma merupakan salah satu } \\
& \text { organisme pengganggu tanaman, } \\
& \text { pertumbuhan gulma yang berada disekitar } \\
& \text { tanaman pokok yang dibudidayakan akan } \\
& \text { mengalami ganguan pertumbuhan akibat } \\
& \text { persaingan terhadap unsur hara, cahaya }
\end{aligned}
$$

mata hari, meningkatnya pertumbuhan hama dan penyebab penyakit tanaman serta bisa menimbulkan kerugian secara ekonomis. Fadly dan Tabri (2008), menyatakan bahwa gulma adalah factor peneyebab berkurang produktifitas dan menjadi competitor bagi tanaman dalam memanfaatkan sumber daya alam yang berguna bagi pertumbuhan.

Mengatasi permasalahan teknik budidaya tanaman bawang merah di tanah masam dapat juga di lakukan dengan pemberian pupuk organik kandang ayam selain bisa menambah unsur hara dalam tanah, juga bisa membuat tanah menjadi subur dan lebih sehat, serta memperbaiki keasaman tanah. Mengaktifkan migroorganisme yang ada didalam tanah, sehingga bisa merubah struktur tanah menjadi lebih gembur dan mampu menahan air lebih lama.

Tujuan utama dari penelitian ini adalah untuk mengetahui tingkat efetifitas Penyiangan Gulma dengan waktu penyiangan berbeda dan untuk mengetahui efektifitas pengunaan pupuk kandang ayam terhadap pertumbuhan dan produksi tanaman bawang merah (Allium ascolanicum, L), serta memperbaiki keasaman tanah. Mengetahui kapan waktu pengendalian gulma yang tetap kerja petani akan lebih efektif, efisien, dan lebih ekonimis. Pemberian pupuk kandang ayam dengan dosis tepat sebagai bahan organik penambah unsur hara dalam tanah dapat menjadikan tanaman bawang merah tumbuh subur.

\section{METODE PENELITIAN}

\section{Lokasi Penelitian}

Penelitian dilaksanakan pada Tahun 2018 di Kebun Percobaan Fakultas Pertanian Universitas Muara Bungo yang terletak pada ketinggian $101 \mathrm{~m}$ di atas permukaan laut, memiliki temperatur udara berkisar 27 ${ }^{0} \mathrm{C}-33{ }^{\circ} \mathrm{C}$.

\section{Rancangan Penelitian}


Penelitian ini menggunakan Rancangan Acak Kelompok (RAK) factorial dengan 3 kelompok .

Faktor pertama 5 perlakuan terdiri atas;

PG0 (tanpa penyiangan gulma)

G1 (disiang 1 kali, yaitu pada umur ; 28 hst)

G2 (disiang 2 kali, yaitu pada umur ; 21, dan 42 hst)

G3 (disiang 3 kali, yaitu pada umur ; 14, 28, dan 42 hst)

G4 (disiang 4 kali, yaitu pada umur ; 7, 14, 21, dan 28 hst)

Faktor kedua 5 perlakuan terdiri atas;

P1 ( 10 ton ha $\left.{ }^{-1}\right)$

P2 ( 20 ton ha $\left.{ }^{-1}\right)$

P4 ( 40 ton ha' ${ }^{-1}$ )

\section{Teknik Analisis Data}

Data hasil pengamatan dianalisis secara statistik dengan sidik ragam, dan apabila $\mathrm{F}$ hitung perlakuan lebih besar dari $F$ table 5\% dilanjutkan dengan uji Uji Beda Nyata Jujur pada taraf 5\%.

\section{Pelaksanaan Penelitian}

Petakkan percobaan dibuat dengan ukuran $100 \mathrm{~cm}$ x $105 \mathrm{~cm}$, Pupuk kandang ayam diberikan kelahan percobaan pada saat pengolahan lahan yaitu 2 minggu sebelum tanam sesuai dengan perlakuan.

Tabel 1.Tinggi Tanaman bawang merah umur 7 MST dengan berbagai Waktu Penyiangan Gulma dan Dosis Pupuk Organik Kandang Ayam pada Tanah Masam.

\begin{tabular}{lccccc}
\hline \multirow{2}{*}{\multicolumn{1}{c}{ Waktu Penyiangan }} & \multicolumn{3}{c}{ Pupuk Organik Kandang Ayam } & $\begin{array}{c}\text { Rata - } \\
\text { Rata }\end{array}$ \\
\cline { 2 - 6 } \multicolumn{1}{c}{ Gulma } & $\begin{array}{c}10 \text { ton } \\
\text { ha }^{-1}\end{array}$ & $\begin{array}{c}20 \text { ton } \\
\text { ha }^{-1}\end{array}$ & $\begin{array}{c}40 \text { ton } \\
\text { ha }^{-1}\end{array}$ & \\
\hline Tanpa Penyianagn & 30,15 & 31,87 & 36.35 & $32,79 \mathrm{ab}$ \\
Penyiangan umur ; 28 hst & 29,33 & 31,05 & 35,53 & $31.97 \mathrm{~b}$ \\
Penyiangan umur ; 21, dan 42 hst & 28,29 & 30,19 & 34,67 & $31.05 \mathrm{bc}$ \\
Penyiangan umur ; 14, 28, dan 42 hst & 28,61 & 30,33 & 33,80 & $30,91 \mathrm{c}$ \\
Penyiangan umur ; 7, 14, 21, dan 28 hst & 27,90 & 29,62 & 34.09 & $30,54 \mathrm{c}$ \\
\hline Rata - Rata & $29.00 \mathrm{~B}$ & $30,61 \mathrm{~B}$ & $34.89 \mathrm{~A}$ & & \\
\hline
\end{tabular}

Keterangan: Angka angka pada baris yang diikuti oleh huruf besar yang sama dan angkaangka pada kolom yang diikuti huruf kecil yang sama menunjukan tidak berbeda menurut uji BNJ pada taraf 5\% 


\section{Jumlah anakan per Rumpun}

Tabel 2. Jumlah Anakan per Rumpun Tanaman Bawang Merah pada berbagai Waktu

Penyiangan Gulma dan Dosis Pupuk Organik Kandang Ayam pada Tanah Masam.

\begin{tabular}{lcccc}
\hline \multirow{2}{*}{$\begin{array}{c}\text { Waktu Penyiangan } \\
\text { Gulma }\end{array}$} & \multicolumn{3}{c}{ Pupuk Organik Kandang Ayam } & $\begin{array}{c}\text { Rata }- \\
\text { Rata }\end{array}$ \\
\cline { 2 - 5 } & $\begin{array}{c}10 \text { ton } \\
\text { ha }^{-1}\end{array}$ & $\begin{array}{c}20 \text { ton } \\
\text { ha }^{-1}\end{array}$ & $\begin{array}{c}40 \text { ton } \\
\text { ha }^{-1}\end{array}$ \\
\hline Tanpa Penyianagn & 5,15 & 5,62 & 5,59 & $5,45 \mathrm{~b}$ \\
Penyiangan umur ; 28 hst & 5,34 & 5,81 & 5,78 & $5,64 \mathrm{~b}$ \\
Penyiangan umur ; 21, dan 42 hst & 5,79 & 6,26 & 6,23 & $6.09 \mathrm{ab}$ \\
Penyiangan umur ; 14, 28, dan 42 hst & 5,86 & 6,32 & 6,29 & $6,16 \mathrm{ab}$ \\
Penyiangan umur ; 7, 14, 21, dan 28 hst & 6,03 & 6,49 & 6,46 & $6,33 \mathrm{a}$ \\
\hline Rata - Rata & $5.63 \mathrm{~B}$ & $6,10 \mathrm{~A}$ & $6,06 \mathrm{AB}$ \\
\hline Keterangan : Angka angka pada baris yang diikuti oleh huruf besar yang sama dan angka- \\
angka pada kolom yang diikuti huruf kecil yang sama menunjukan tidak \\
berbeda menurut uji BNJ pada taraf 5\%
\end{tabular}

3. Jumlah Daun (helai)

Tabel 3. Jumlah Daun Tanaman Bawang Merah pada berbagai Waktu Penyiangan Gulma dan Dosis Pupuk Organik Kandang Ayam pada Tanah Masam.

\begin{tabular}{lcccc}
\hline \multirow{2}{*}{\multicolumn{1}{c}{ Waktu Penyiangan }} & \multicolumn{2}{c}{ Pupuk Organik Kandang Ayam } & $\begin{array}{c}\text { Rata }- \\
\text { Gulma }\end{array}$ \\
\cline { 2 - 5 } \multicolumn{1}{c}{\begin{tabular}{c} 
Gulm \\
\cline { 2 - 5 }
\end{tabular}} & $\begin{array}{c}10 \text { ton } \\
\text { ha }^{-1}\end{array}$ & $\begin{array}{c}20 \text { ton } \\
\text { ha }^{-1}\end{array}$ & $\begin{array}{c}40 \text { ton } \\
\text { ha }^{-1}\end{array}$ \\
\hline Tanpa Penyianagn & 16,71 & 17,41 & 21,66 & 18,59 \\
Penyiangan umur ; 28 hst & 16,43 & 18,04 & 21,96 & 18,81 \\
Penyiangan umur ; 21, dan 42 hst & 16,46 & 18,22 & 22,77 & 19,15 \\
Penyiangan umur ; 14, 28, dan 42 hst & 16,70 & 18,76 & 24,01 & 19,83 \\
Penyiangan umur ; 7, 14, 21, dan 28 hst & 16,53 & 17,59 & 22,84 & 18,99 \\
\hline Rata - Rata & $16,57 \mathrm{~B}$ & $18,01 \mathrm{~B}$ & $22,85 \mathrm{~A}$ & \\
\hline
\end{tabular}

Keterangan: Angka angka pada baris yang diikuti oleh huruf besar yang sama dan angkaangka pada kolom yang diikuti huruf kecil yang sama menunjukan tidak berbeda menurut uji BNJ pada taraf $5 \%$

\section{Bobot Umbi per Rumpun (gram)}

Tabel 4. Bobot Umbi per Rumpun pada berbagai Waktu Penyiangan Gulma dan Dosis Pupuk Organic Kandang Ayam pada Tanah Masam.

\begin{tabular}{lcccc}
\hline \multirow{2}{*}{\begin{tabular}{c} 
Waktu Penyiangan \\
\multicolumn{1}{c}{ Gulma }
\end{tabular}} & \multicolumn{2}{c}{ Pupuk Organik Kandang Ayam } & $\begin{array}{c}\text { Rata }- \\
\text { Rata }\end{array}$ \\
\cline { 2 - 5 } & $\begin{array}{c}10 \text { ton } \\
\text { ha }^{-1}\end{array}$ & $\begin{array}{c}20 \text { ton } \\
\text { ha }^{-1}\end{array}$ & $\begin{array}{c}40 \text { ton } \\
\text { ha }^{-1}\end{array}$ \\
\hline Tanpa Penyianagn & 25,86 & 30,94 & 49,02 & $35,27 \mathrm{c}$ \\
Penyiangan umur ; 28 hst & 25,84 & 31,17 & 49,00 & $35,34 \mathrm{bc}$ \\
Penyiangan umur ; 21, dan 42 hst & 33.06 & 38,39 & 56,22 & $42,56 \mathrm{a}$ \\
Penyiangan umur ; 14, 28, dan 42 hst & 29,33 & 34,66 & 52,49 & $42,16 \mathrm{a}$
\end{tabular}


Penyiangan umur ; 7, 14, 21, dan 28 hst $\quad 27,87 \quad 33,20 \quad 51,03 \quad 37,37$ b

\begin{tabular}{cl}
\hline Rata - Rata & \multicolumn{2}{c}{ 28,39C $\quad 33,47 \mathrm{~B} \quad 51,55 \mathrm{~A}$} \\
\hline Keterangan: & $\begin{array}{l}\text { Angka angka pada baris yang diikuti oleh huruf besar yang sama dan angka- } \\
\text { angka pada kolom yang diikuti huruf kecil yang sama menunjukan tidak } \\
\text { berbeda menurut uji BNJ pada taraf 5\% }\end{array}$
\end{tabular}

\section{Bobot Umbi per Petak (gram)}

Tabel 5.Bobot umbi per Petak pada berbagai Waktu Penyiangan Gulma dan Dosis Pupuk Organik Kandang Ayam pada Tanah Masam.

\begin{tabular}{|c|c|c|c|c|}
\hline \multirow{2}{*}{$\begin{array}{c}\text { Waktu Penyiangan } \\
\text { Gulma }\end{array}$} & \multicolumn{3}{|c|}{ Pupuk Organik Kandang Ayam } & \multirow[t]{2}{*}{$\begin{array}{c}\text { Rata - } \\
\text { Rata }\end{array}$} \\
\hline & $\begin{array}{l}10 \text { ton } \\
\mathrm{ha}^{-1}\end{array}$ & $\begin{array}{c}20 \text { ton } \\
\text { ha }^{-1}\end{array}$ & $\begin{array}{c}40 \text { ton } \\
\mathrm{ha}^{-1}\end{array}$ & \\
\hline Tanpa Penyianagn & 726,34 & 816,01 & $1.240,67$ & $927,67 b$ \\
\hline Penyiangan umur ; 28 hst & 727,15 & $816,, 82$ & $1.241,48$ & $928,48 b$ \\
\hline Penyiangan umur ; 21, dan 42 hst & $844,, 47$ & 934,40 & $1.358,80$ & $1.045 .89 \mathrm{a}$ \\
\hline Penyiangan umur ; 14, 28, dan 42 hst & 881.65 & 971,32 & $1.395,98$ & $1.082 .98 \mathrm{a}$ \\
\hline Penyiangan umur ; 7, 14, 21, dan 28 hst & 772,47 & 862,14 & $1.283,80$ & $972,803 \mathrm{ab}$ \\
\hline Rata - Rata & $790,42 B$ & $840,, 54 \mathrm{~B}$ & $1.02495 \mathrm{~A}$ & \\
\hline $\begin{array}{l}\text { Angka angka pada baris y } \\
\text { angka pada kolom yang } \\
\text { berbeda menurut uji BNJ }\end{array}$ & diikuti ol & huruf bes & $r$ yang sam & ka \\
\hline
\end{tabular}

\section{PEMBAHASAN}

Tabel 1 menunjukan bahwa waktu penyiangan gulma tidak berinteraksi dengan pemberian pupuk organik kandang ayam. Waktu penyiangan gulma yang berbeda memberikan perbedaan terhadap tinggi tanaman bawang merah, tinggi tanaman dengan tanpa penyiangan gulma memberikan pengaruh yang berbeda teradap penyiangan gulma satu kali umur 28 hst, dua kali umur 21 dan 42 hst, tiga kali umur 14, 28, dan 42 hst, empat kali umur 7, 14, 21, dan 28 hst. Tinggi tanaman bawang merah tanpa dilakukan penyiangan memperlihat hasil terbaik tetapi tanamannya kelihatan kurus, hal ini disebabkan karena banyaknya gulma yang tumbuh disekitar tanaman sehingga mengakibatkan terjadinya persaingan terhadap cahaya matahari, air, kelembaban dan unsur hara. Sempitnya rungan gerak tanaman yang tumbuh disekitar gulma mengakibatkan pertumbuhan tanaman lebih cenderung tumbuh keatas tetapi kondisi tanaman menjadi kurang subur akibat kurangnya maksimalnya tanaman mendapat unsur hara.

Cahaya matahari dibutuhkan tanaman dalam proses fotosisntesis, respirasi, sertan pertumbuhan dan perkembangan tanaman. Menurut (Woodward dan Sheely, 1983), pengaruh cahaya terhadap tanaman sangat kompleks, yaitu mempengaruhi proses fotokimia, juga bentuk dan ukuran tanaman. Hal ini sejalan dengan pendapat Jatmiko et al. (2002) gulma berinteraksi dengan tanaman melalui persaingan untuk mendapatkan satu atau lebih faktor tumbuh yang terbatas, seperti cahaya, hara dan air. Tingkat persaingan bergantung pada curah hujan, varietas, kondisi tanah, kerapatan gulma, lamanya tanaman, pertumbuhan gulma, serta umur tanaman saat gulma mulai bersaing.

Peningkatan dosis pupuk organik kandang ayam yang diberikan pada tanaman bawang merah memperlihatkan 
perbedaan tinggi tanaman. Dosis pupuk 40 ton $\mathrm{h}^{-1}$ memberikan pertumbuhan tinggi tanaman terbaik, disebabkan karena pada kondisi tanah masam peran pupuk organik kandang ayam tidak hanya sebagai penyedia unsur hara makro terutama $\mathrm{N}, \mathrm{P}$, $\mathrm{K}$ dan mikro dalam tanah tetapi juga bisa meningkatkan $\mathrm{pH}$ tanah, serta memperbaiki sifat fisik tanah yaitu, struktur, permeabilitas dan pori-pori tanah, konsistensi dan suhu tanah. Ketersediaan unsure $\mathrm{N}$ dan $\mathrm{P}$ yang cukup dalam tanah serta didukung juga dengan keadaan $\mathrm{pH}$ tanah yang diinginkan tanaman, dapat membantu tanaman untuk bertambah tinggi dan juga untuk pertumbuhan lainnya,

Menurut Yelni (2015), kemampuan tanaman bawang merah dalam memanfaatkan unsure hara $\mathrm{N}$ dan $\mathrm{P}$ yang tersedia dalam tanah secara optimal dapat membantu pertumbuhan vegetative seperti tinggi tanaman menjadi lebih baik, dan bila kandungan unsure hara $\mathrm{N}$ dan $\mathrm{P}$ tidak terpenuhi maka dapat mengakibatkan tanaman menjadi tumbuh kerdil, serta kekurangan unsure hara $\mathrm{N}$ mempengaruhi penyerapan unsure hara $\mathrm{P}$ dan $\mathrm{K}$ oleh tanaman.

Alam et al (2004), menyatakan bahwa pemberian pupuk kandang ayam berpengaruh terhadap sifat kimia tanah, yang dapat meningkatkan $\mathrm{C}$ organik, $\mathrm{N}, \mathrm{P}$, dan $\mathrm{K}$ yang dapat meningkatkan $\mathrm{pH}$ tanah. Ditambahkan lagi oleh menyatakan Utami et al (2012) bahwa pupuk kandang ayam memiliki kandungan unsur hara $\mathrm{N}, \mathrm{P}$, dan $\mathrm{K}$ yang lebih banyak dibanding pupuk kandang lainnya.

Tabel 2 menunjukan bahwa waktu penyiangan gulma tidak berinteraksi dengan pemberian pupuk organik kandang ayam. Perlakuan penyiangan gulma pada tanaman bawang merah yang berbeda menunjukan perbedaan terhadap pembentukan anakkan tanaman, semangkin sering penyiangan gulma dilakukan maka kemungkinan persaingan terhadap pemanfaatan cahaya matahari, kelembaban dan unsur hara yang ada didalam tanah dengan gulma yang tumbuh disekitar tanaman bisa diminimalkan, sehingga tanaman pokok bisa lebih leluasa tumbuh dan berkembang terutama pada fase pembentukan anakkan. Penyiangan gulma sebanyak dua kali yaitu umur 21 dan 42 hst memberikan efek terhadap pembentukan anakan tanaman yang lebih baik dibandingkan dengan tanpa penyiangan, satu kali, tiga kali dan empat kali penyiangan dengan waktu penyiangan yang berbeda-beda.

Menurut Sukman dan Yakup (2002), kehadiran gulma tidak setiap saat merugikan tanaman. Kehadiran gulma pada periode permulaan siklus hidup tanaman dan pada periode menjelang panen pengaruhnya sangat kecil, sehingga gulma yang tumbuh pada periode itu tidak perlu dikendalikan, akan tetapi diantara dua periode tersebut tanaman peka terhadap gulma yang dinyatakan sebagai periode kritis persaingan gulma, kerapatan gulma yang tumbuh dan periode kritis tanaman akan sangat menentukan waktu penyiangan yang tepat.

Pemberian pupuk organik kandang ayam dengan dosis 20 ton $\mathrm{h}^{-1}$ pada penelitian memberikan pengaruh efektif terhadap pembentukan anaKkan tanaman bawang merah, peningkatan dosis pupuk yang diberikan penagruhnya tidak signifikan. Hal ini disebabkan karena dengan pemberian dosis pupuk yang tepat dan ketersediaan air yang cukup tanaman bisa maksimal memanfaatkan unsur hara terutaman unsur $\mathrm{P}$ yang tersedia untuk proses perbanyakan anakkan. Unsur hara $\mathrm{P}$ juga berfungsi dalam proses pembentukan akar yang sehat, kuat dan panjang, pertumbuhan system perakaran yang maksimal dapat membantu mempercepat proses metabolism tanaman.

Sarief (1985), menyatakan bahwa kotoran ayam selain dapat menyumbangkan hara makro yang tinggi (terutama $\mathrm{N}, \mathrm{P}$ dan $\mathrm{K}$ ) juga dapat menyumbangkan hara mikro seperti $\mathrm{Fe}$, $\mathrm{Zn}$, dan Mo serta kotoran ayam mengandung kadar air dan nisbah $\mathrm{C} / \mathrm{N}$ 
yang rendah, sehingga akan mempercepat proses mineralisasi dan memperkecil tekanan nitrat di dalam tanah. Dengan demikian ketersediaan unsur hara yang diperoleh dari kotoran ayam lebih cepat. Menurut Yetti dan Elita (2008), untuk meningkatkan jumlah anakkan bawang merah perlu diberikan tambahan pupuk NPK yang bersumber dari bahan organik sebagai sumber energy untuk proses pertumbuhan tanaman.

Tabel 3 menunjukan bahwa waktu penyiangan gulma tidak berinteraksi dengan pemberian pupuk organik kandang ayam. Perlakuan penyiangan gulma pada tanaman bawang merah yang berbeda menunjukan perbedaan terhadap pembentukan jumlah daun tanaman. Waktu penyiangan gulma disekitar tanaman bawang merah yang masih aktif tumbuh mempengaruhi proses pembentukan daun. Penyiangan gulma yang dilakukan pada umur tanaman 28 HST sangat efektif karena setelah karena pada umur 32 sampai 42 HST tanaman bawang merah mengalami proses pembentukan umbi sebagai penentu jumlah anakkan yang terbentuk dan selajutnya diikuti proses pembentukan daun, semangkin banyak anakkan maka jumlah daun juga semangkin banyak. Pada fase tersebut gangguan yang disebabkan oleh tumbuhnya gulma harus dihindarkan sehingga pertumbuhan daun akan terbentuk maksimal.

Gulma memiliki daya kompetitif yang sangat tinggi, sehingga memungkinkan dirinya untuk bersaing mendapatkan sumber daya yang sama dengan tanaman budidaya (Palijama et al, 2012). Menurut Loux et al. (2015) gulma dapat menghasilkan senyawa alelopati yang menghambat pertumbuhan tanaman budidaya.

Pemberian pupuk organic kandang ayam sebanyak 40 ton $\mathrm{h}^{-1}$ merupakan dosis yang tepat pada penelitian ini, dibanding dengan dosis yang lain, karena pada dosis tersebut ketersediaan unsure hara esemsial yang dibutuhkan untuk http://ojs.umb-bungo.ac.id/index.php/saingro/index

pertumbuhan daun tanaman bawang merah secara maksimal dapat terpenuhi dan juga bisa memperbaiki keadaan $\mathrm{pH}$ tanah, sehingga jumlah daun tanaman tumbuh optimal. Pada fase pertumbuhan tanaman membutuhkan unsure hara Nitrogen yang cukup banyak.

Lingga dan Marsono (2008), bahwa peranan utama Nitrogen bagi tanaman adalah untuk merangsang pertumbuhan secara keseluruhan, khususnya batang, cabang dan daun. Karena dalam fase generatif tanaman bawang merah dalam hal ini pertumbuhan tanaman dengan pembentukan daun jika tanaman mengalami pertumbuhan yang baik dan membentuk daun dengan sempurna maka proses pembentukan umbi juga akan maksimal.

Tabel 4 dan 5. Produksi tanaman bawang merah, efektifitas terhadap waktu penyiangan gulma yang dilakukan memberikan pengaruh terhadap produksi hasil umbi tanaman bawang merah . Penyiangan gulma pada umur tanaman 21 HST dan 42 HST merupakan waktu penyiangan yang terbaik terhadap hasil produksi tanaman bawang merah di tanah masam, hal ini disebabkan karena pada fase pembentukan umbi tanaman memerlukan kondisi areal tempat tumbuh tidak terjadi kompetisi terhadap ketersediaan cahaya matahari dan unsur hara, disamping tanaman juga memerlukan kelembaban yang cukup tinggi. Kondisi gulma dengan kapasitas jumlah sedikit, tidak rapat, dan pertumbuhannya tidak melebihi tanaman budidaya dapat membantu kelembaban disekitar tanaman di tanah-tanah kering dan masam.

Sesui dengan pendapat Sembodo (2010), menyatakan pada tingkat populasi gulma yang rendah persaingan antara tanaman dengan gulma belum terjadi sehingga kehilangan hasil belum terlihat. Sedangkan saat gulma melebihi batas ambang kerusakan tanaman maka pada tingkat populasi itulah hasil tanaman menurun. 
Dosis pupuk organic kandang ayam sebanyak 40 ton $\mathrm{h}^{-1}$ yang diberikan dapat memperbaiki sifat fisik dan $\mathrm{pH}$ tanah, sehingga tanah lebih gembur dan subur. Petumbuhan umbi tanaman bawang merah pada penelitian ini hampir sama dengan deskripsi varietas. Hal ini diduga bahwa pupuk organic kandang ayam yang diberikan kedalam tanah terpenuhi, pertumbuhan umbi dan produksi tanaman meningkat dibanding dengan dosis yang lain. Kandungan unusr hara esensial seperti unsur $\mathrm{K}$ yang tersedia dalam tanah dapat membantu pertumbuhan umbi tanaman.

Sumadi dan Cahyono (2005) menyatakan bahwa peran Kalium dalam tanaman yaitu membantu proses fotosintesa untuk pembentukan senyawa organik baru yang akan diangkut ke organ tempat penimbunan, dalam hal ini umbi dan sekaligus memperbaiki kualitas umbi tersebut.

Menurut Alam et al, 2014), selain mengandung $\mathrm{N}$ dan $\mathrm{P}$ yang cukup tinggi kompos kotoran ayam juga mengandung Kalium yang tinggi, yang berperan sebagai aktifator enzim dalam metabolisme karbohidrat dan nitrogen yang meliputi pembentukan, pemecahan dan translokasi pati, serta berpengaruh terhadap pengangkutan fosfor

\section{KESIMPULAN}

1. Waktu pengendalian gulma yang efektif dalam meningkatkan pertumbuhan jumlah anakan dan produksi tanaman bawang merah adalah, waktu penngendalian gulma sebanayk 2 kali yaitu pada umur 28 dan 42 HST

2. Dosis 40 ton $\mathrm{h}^{-1}$ pupuk organik kandang ayam cukup efektif membantu pertumbuhan tinggi tanaman, jumlah daun dan meningkatkan bobot umbi tanaman bawang merah, serta memperbaiki kondisi $\mathrm{pH}$ tanah masam

\section{Daftar Pustaka}

Alam, S. M, Tufaila, Dewi D,C. (2014). Aplikasi Kompos Kotoran Ayam Untuk Meningkatkan Hasil Tanaman Mentimun (cculcumis sativus, L) Ditanah Masam. Jurnal Agroteknos. Vol. 4. No 2 Hal 119-126.

BPS, 2010. Bungo Dalam Angka. Biro Statistik Muara Bungo. Jambi

BPS, 2017 Produktivitas, Luas Panen dan Produktivitas Sayuran Seyuran di Indonesia. Badan Pusat Statistik Republik Indonesia, Jakarta.

Fadly AF, Tabri F. 2008. Pengendalian Gulma pada Tanaman Jagung. Maros: Balai Penelitian Tanaman Serealia.

Hartatik,

W.,

L.R.

Widowati.2005.Pengaruh Kompos Pupuk Organik yang Diperkaya dengan Bahan Mineral dan Pupuk Hayati terhadap Sifat-sifat

Loux, M. M., D. Doohan, A. F. Dobbles, W.G. Jhonson, B.G. Young, T.T.Legleiter, dan A. Hagher. 2015. Weed Control Guide for Ohio, Indiana, and Illinois. The Ohio State University. Columbus.

Palijama, W. J. Riry, dan A.Y. Wattimena. 2012. Komunitas Gulma pada Pertanaman Pala (Myristica fragrans $\mathrm{H}$.) Belum mengasilkan dan Mengahasilkan di Desa Huttumuri kota Ambon Agrologia. 1(2): $91-169$.

Sarief, E. Saifuddin. 1985. Kesuburan dan Pemupukan Tanah Pertanian. Pustaka

Sembodo, D.R.J. 2010. Gulma dan Pengelolaannya. Graha Ilmu. Yogyakarta. 163 hal.

Sukman, Y. dan Yakup. 2002 Gulma dan teknik pengendaliannya. Fakultas Pertanian Universitas Sriwijaya Palembang. Raja Grafindo Persada. Jakarta. 
Woodward, F.I. and J.E. Sheely. 1983. "Principles and measurements in environmental biology". Butterworth \& Co (Publishers) Ltd. $263 \mathrm{p}$.

Yelni, G. 2015. Pengaruh Pemberian Pupuk Organik Tandan kosong Kelapa Sawit Terhadap Kandungan Klorofil Bawang Merah (Allium Aascolanicum L.) diultisol. Jurnal Ekotrans Vol.15.Pusat Studi Ekonomi danSosial Lembaga Penelitian dan Pengabdian Masyarakat Universitas Ekasakti Padang.

Yetti, H., dan Elita, E. 2008. Pengaruh Pupuk Organik dan KCL pada Tanaman Bawang Merah. Fakultas Pertanian Universitas Riau. Sagu Vol. 7 (1): 13 -18 